\title{
Justicia y Territorialidad Indígena. La Experiencia del Juzgado de Primera Instancia de la Puna Jujeña (1850-1870)
}

\author{
Justice and Indigenous Territoriality. The Experience of \\ the Court of First Instance of the Puna Jujeña (1850-1870)
}

Cecilia Fandos

Universidad Nacional de Jujuy CONICET, Argentina

Recibido: 01/03/2018

Aceptado: 15/04/2018

Resumen: En la conformación del orden liberal decimonónico el territorio de la Puna en la provincia de Jujuy, Argentina, presenta como faz ineludible de análisis la articulación de los grupos indígenas en los procesos de construcción de los Estados nacionales republicanos (observables en acciones contestatarias y en las estrategias de negociación y de adaptación), por ser un escenario con una nutrida presencia de estos actores sociales. Escogiendo como mirador de la temática al ámbito de la justicia y la conflictividad social, en este artículo se estudia las circunstancias de creación y la trayectoria de funcionamiento del Juzgado de Primera Instancia en la Puna. Mediante el examen de diferentes fuentes de los archivos históricos de Jujuy nos proponemos comprender esta experiencia como una respuesta estatal ajustada a las voces emitidas y manifestaciones emanadas por “justicia”, de su población local.

Palabras Claves: orden liberal, justicia local, conflictividad social, acción indígena

Abstract: In the constitution of the nineteenth-century liberal order, the Puna territory in the province of Jujuy, Argentina, presents, as an unavoidable facet of analysis, the involvement of indigenous groups in the construction of 
republican national states (which can be seen in defiant actions and in strategies of negotiation and adaptation), owing to the fact that the province had a strong presence of these social actors. This article proposes to study, from a perspective inclined towards the field of justice and social divisiveness, the circumstances in which the Court of First Instance in the Puna was created and the trajectory of its functioning. By examining different sources from the historic archives of Jujuy, we attempt to understand this experience as a state response compliant with the voices and manifestations produced by "the justice" of its local population.

Keywords: liberal order, local justice, social divisiveness, indigenous action

\section{Introducción}

El cinco de marzo de 1871, Matías Ábila en una correspondencia dirigida al gobernador de la provincia, expedida en Yavi, como Juez de Primera Instancia de la Puna expresaba un cúmulo de sentimientos encontrados a consecuencia de los retos de su flamante cargo. Así, pronunciaba alguna desorientación sobre la línea de conducta a seguir de cara a determinados hechos, también la pujanza para impulsar su misión solicitando la provisión de todos los recursos necesarios a fin optimizar este juzgado. Además, sus palabras traslucían el temor por la seguridad -suya y de todos- frente al estado de las cárceles, ante cuya situación se veía obligado a ordenar el uso del cepo en las noches para evitar las habituales fugas. También reflejaban la extrañeza sobre algunas prácticas en la administración de la justicia que, en definitiva, dejaba poblaciones enteras desprovistas de la misma, señalando que

\footnotetext{
"En estos departamentos hay un abuso pernicioso, el que no deja de traer sus dificultades [...] Los Comisarios, Jueces y alguna vez, hasta los suplentes hacen sus biajes (sic), sea a Bolivia o para abajo, y al ausentarse dejan en su lugar otro individuo que no es nombrado Comisario, ni Juez y llegara vez que suceda un conflicto por la ausencia de estos [...] Yo he visto en Cochinoca en años anteriores marcharse [...] todos los vecinos y no quedar más que el cura y sacristan (sic), este último no sabía ni escribir, y dejarlo al Cura de Juez". ${ }^{1}$
}

\footnotetext{
${ }^{1}$ Archivo Histórico de Jujuy, Argentina, (en adelante AHJ), Caja Documentos, Año 1871, Yavi, 5 de marzo de 1871.
} 
A su vez, en la misiva, se plasmaba el descrédito de Ábila respecto a sus posibilidades para actuar como autoridad superior frente a los vicios en el ejercicio del poder por las arbitrariedades que cometían los comisarios, los jueces y los capataces de los cuatro departamentos de la Puna, expresando en estos términos su estrecho margen de acción: "asi, es que el indio es víctima de todos sin que yo pueda pedir explicaciones". ${ }^{2}$

Era la segunda vez en menos de diez años que el Estado provincial procuraba dotar a la Puna de un juzgado de primera instancia; creado por una ley de 1859 había funcionado fugazmente durante catorce meses entre 1864 y 1865. Esta decisión, muy costosa para unas endebles arcas públicas, no fue infundada ni fortuita. Por el contrario, amén del único otro juzgado del tipo establecido en la capital provincial, se buscaba intervenir con la presencia de este organismo de justicia en una de las regiones geográficamente más alejadas, en las fronteras con Bolivia y Chile, y "díscolas", del centro administrativo y gubernamental. A mediados del siglo XIX, allí se concentraba todavía la mayor de la población (con un 30\% del total de Jujuy) 3 y estaban establecidas enormes y de las más ricas haciendas de la provincia (sin contar las propiedades urbanas cercanas a la ciudad capital, en los departamentos de la Puna se hallaba la principal riqueza inmobiliaria rural provincial). Estas haciendas se orientaban principalmente a la percepción de cuantiosas rentas generadas en los pagos y servicios personales que la masa indígena de campesinos indígena hacía en concepto de arriendos, para el pastoreo de ganado en pequeña escala. 4

La Puna, una meseta de altura por encima de los 3.000 metros sobre el nivel del mar y un "desierto" frío y seco extremo, condensaba el escenario característico de las sociedades andinas con una numerosa y perdurable población indígena, salpicada de la presencia de mestizos y blancos en las

\footnotetext{
2 AHJ, Caja Documentos, Año 1871, Yavi, 5 de marzo de 1871.

3 Esta tendencia se fue paulatinamente revirtiendo hasta provocar un fuerte "estancamiento de la población" de la Puna, por muerte y migración -sobre todo masculina- a consecuencia de la precarización de su economía y la combinación de guerras, sequías y epidemias. GIL MONTERO, Raquel, "Población, medio ambiente y economía en la Puna de Jujuy, Argentina, Siglo XIX”, Revista de Demografía Histórica, Asociación de Demografía Histórica, vol. XXII, ${ }^{\circ}$ 1, 2004, pp. 185-208.

4 MADRAZO, Guillermo, Hacienda y encomienda en los Andes. La Puna de Jujuy bajo el marquesado de Tojo, siglos XVII-XIX, Buenos Aires, Fondo Editorial, 1982.
} 
pueblos cabeceras, que desde el orden colonial al sistema republicano mudaron su condición de súbditos de la "República de Indios" a la de "Ciudadanos" de una Nación, resignando con ello los sistemas de gobierno y autoridades propias, las obligaciones tributarias y el acceso a recursos como la tierra a través de la propiedad comunal.

La expresión más sonada y conocida de estos procesos in situ fue la extendida oleada de rebelión indígena en todas las tierras altas de Jujuy durante la década de 1870,5 en la que se denunciaron derechos de propiedad indebidos y crónicos atropellos en la cobranza y sistemas de arrendamientos. La movilización se cerró, en una primera etapa, con la expropiación de una parte importante del patrimonio de un poderoso local -el Marqués de Yavi- y su conversión en tierra fiscal. Pero, se sabe, el "problema indígena" andino no estuvo supeditado solo a la "cuestión de la tierra"; la construcción de los Estados liberales generó conflictos, litigios, negociaciones, adaptaciones, en muchos otros frentes, reconfigurando las relaciones sociales de estos ámbitos rurales.

En el complejo marco de este proceso, es a través del análisis de la organización de la justicia, particularmente de la creación y funcionamiento del Juzgado de Primera Instancia de la Puna, que intentamos desentrañar el tejido de relaciones sociales de la región en estudio, del que un gran componente eran los sectores indígenas. Nos preguntamos si su fundación fue únicamente parte de las acciones de institucionalización del Estado provincial con miras a ejercer el control social o si también fue una respuesta a la presión emanada de un cuadro social expuesto, muy tenso e "injusto" que no se podía obviar. ¿Cuál fue el origen causal de este Juzgado? ¿Fue una vía que canalizó el descontento social de los sectores subalternos? ¿Cómo funcionó, qué causas trató, en qué contexto, porqué dejó de funcionar? Por su intermedio, ¿̇e intervinieron las relaciones de poder local?

Intentamos dar respuesta a estos interrogantes explorando la correspondencia oficial e informes expedidos por diferentes autoridades de la Puna contenidos en el Archivo Histórico Provincial, y los debates legislativos que en materia de justicia se libraron en la legislatura local entre las décadas de

5 La convulsión se manifestó en los departamentos de Cochinoca, Yavi, Santa Catalina y Rinconada, en la Quebrada de Humahuaca (Humahuaca y Tilcara). 
1850 y 1870 que se encuentran en el Archivo de la Legislatura de Jujuy. En el artículo ubicamos en un primer apartado las principales interlocuciones teóricas y metodológicas de las que nos hemos valido en el abordaje de la problemática. Luego, recorremos las principales marcas de organización de la justicia en la provincia a partir de su configuración como Estado autónomo (1834) y las instancias legislativas y situacionales de la creación del juzgado en la Puna. Al final se describe el funcionamiento del Juzgado de Primera Instancia de la Puna: autoridades, actuaciones, significados. Allí destacamos la importancia de este juzgado en la tramitación de causas por abuso de autoridad.

\section{Interlocuciones teóricas y reflexiones historiográficas. Construyendo nuestro objeto de estudio}

Detenernos en el análisis pormenorizado de la experiencia del Juzgado de Primera Instancia de la Puna es una decisión estimulada, sin duda, por la posibilidad de entablar un fecundo y sugestivo diálogo con los nuevos enfoques teóricos y metodológicos procedentes del campo de la historia de la justicia. $\mathrm{Su}$ desarrollo ha contribuido a mirar la relación "entre la ley y el derecho, entre la ley y el Estado (y el ejercicio del poder) o entre la ley y la sociedad" de un modo mucho más complejo, al entenderse éstas como interrelaciones "multidireccionales de continua negociación que afectan a la propia comprensión de cada uno de los elementos implicados". 6

Con una extensa agenda bibliográfica sobre la materia -improbable de resumirse en este trabajo-, su lectura favorece la recreación de ciertas problemáticas y complejiza los interrogantes. Como sostienen algunos expertos, los puntos de partida para llegar a la historiografía reciente sobre la justicia son diversos -en muchos casos subproductos de otras líneas de indagación-7 y con un inventario temático muy amplio -los que van desde los estudios

\footnotetext{
${ }^{6}$ GALANTE, Mirian, "La historiografía reciente de la justicia en México, siglo XIX: perspectivas, temas y aportes", Revista Complutense de Historia de América, Universidad Complutense de Madrid, vol. 37, 2011, p. 95.

7 TÍO VALLEJO, Gabriela, “Los historiadores 'hacen justicia': un atajo hacia la sociedad y el poder en la campaña rioplatense en la primera mitad del siglo XIX", Revista de historia del derecho, Instituto de Investigaciones de Historia del Derecho, $\mathrm{n}^{\circ}$ 41, enero-junio 2011, pp. 199212. Recuperado el 24 de febrero de 2018, de http://www.scielo.org.ar/scielo.php?script=sci arttext\&pid=S1853$\underline{17842011000100006 \& \ln g=e s \& t \operatorname{lng}=\text { es. }}$.
} 
prosopográficos de la administración de la justicia a las prácticas y culturas jurídicas, las proyecciones de la justicia de Antiguo Régimen a la República, entre otros- .8

En nuestro caso han sido medulares algunos protocolos de investigación centrados en la construcción del poder en los ámbitos rurales, como el espacio rioplatense, que retoman la justicia como una instancia de doble observación, por una parte, de la acción estatal desplegada sobre la sociedad rural y, por otra, de la "configuración de conflictos y solidaridades en los que tienen intervención los poderes locales formales e informales y los actores sociales subalternos". 9

Estas formas de encarar el estudio de la justicia se entroncan con una corriente mucho más amplia que viene revisando los propios conceptos de "Poder", "Estado", "Hegemonía" y "Subalternidad". Con esta vista ha perdido preeminencia la dicotomía Estado-sociedad, para entender que en los procesos de institucionalización estatal intervienen "la "racionalidad establecida" (reglas, formas sociales o códigos) y los acontecimientos/ desarrollos/ movimientos sociales que se apoyan implícita o explícitamente en dicha racionalidad y/o la cuestionan".10 En el razonamiento de la autora citada, la acción social es comprendida como un fenómeno con autonomía más que como reflejos "aditivos", mecánicos, de las relaciones de producción o de la estructura del Estado. Y, en paralelo, la idea de Estado es cuestionada como sujeto con absoluta supremacía e independencia adscribiéndose a la línea de la teoría "pluralista del Estado". 11

Desde esas ópticas de la relación entre Estado y sociedad cobra relieve la dimensión del mundo jurídico y judicial en interrelación con los actores sociales (individuales y colectivos). Al ceñir la temática al siglo XIX, esta adquiere propiedades específicas por el marco que le otorga la consolidación de los

8 BARRIERA, Darío, "Justicias, jueces y culturas jurídicas en el siglo XIX rioplatense", Nuevo Mundo Mundos Nuevos [en línea], 23 de marzo de 2010. Recuperado el 23 de febrero de 2018 de http://journals.openedition.org/nuevomundo/59252

9 FRADKIN, Raúl, "La experiencia de la Justicia: Estado, propietarios y arrendatarios en la campaña bonaerense (1800-1830)", Raúl FRADKIN (comp.), 'La ley es la tela de araña'. Ley justicia y sociedad rural en Buenos Aires, 1780-1830, Buenos Aires, Prometeo, 2009, p. 84.

10 IRUROZQUI, Marta, "Presentación: Otra vuelta de tuercas. Justicia y violencia política en Iberoamérica, siglo XIX", Revista de Indias, Consejo Superior de Investigaciones Científicas, vol. LXXVI, $\mathrm{n}^{\circ}$ 266, 2016, p. 4.

${ }^{11}$ Ibidem, pp. 4-6. 
Estados nacionales. Efectivamente, reinó entonces una pretensión manifiesta de imponer un "absolutismo jurídico", ${ }^{12}$ basado en una concepción individualista de la sociedad.

Situada la cuestión en América Latina se añaden patrones propios a los parámetros seguidos en todo el mundo occidental durante este proceso. En este espacio el nuevo orden liberal decimonónico con base en el principio de la soberanía popular se fundó en un proceso de homogenización que debía borrar cualquier diferencia jurídica de la población y generar una identidad uniforme; la de la unidad nacional.13 En las regiones donde la presencia indígena era importante una pregunta central de análisis es cómo se articularon y cómo respondieron las poblaciones indígenas a la configuración liberal. Durante mucho tiempo la contestación al gran interrogante fue la inacción, la ausencia, el silencio, la separación, la anulación. Ahora imperan otras propuestas analíticas que invierten la perspectiva y develan un sujeto indígena activo. ${ }^{14}$

Con un fuerte sesgo en la problemática de la desamortización de las propiedades comunales y la consecuente y perdurable disputa por los derechos y formas de acceso a la tierra, entendemos que gran parte de estos temas y enfoques siguen ausentes de las investigaciones sobre las sociedades indígenas de Jujuy del siglo XIX.15 Un estudio de base que tiene la gran virtud de esbozarlos, aun cuando el cuadro de diálogo teórico con el que se contaba era radicalmente otro, es el de Guillermo Madrazo. En su libro publicado en 1982 se aboca a la historia de unas haciendas (de la puna salto-jujeña y el valle de Tarija en Bolivia) y una encomienda (Casabindo y Cochinoca) ligadas al Marquesado

12 GROSSI, Paolo, "Absolutismo jurídico y derecho privado en el siglo XIX", Derecho \& Sociedad, $\mathrm{n}^{\circ}$ 11, Facultad de Derecho de la PUCP, 1996, pp. 94-99. Recuperado el 2 de febrero de $2018 \mathrm{de}$ http://revistas.pucp.edu.pe/index.php/derechoysociedad/issue/view/1215. Este concepto apunta a la idea de un sistema jurídico que está monopolizado por el Estado, es opuesto a la idea de orden jurídico pluralista del Antiguo Régimen. Así diferentes aspectos de la vida privada -nacimiento, muerte, etc.- son hechos jurídicos regulados y administrados por el Estado, que se arroga la facultad exclusiva de dictar el "Derecho": el que se convierte, además, en sinónimo de Ley.

13 QUIJADA, Mónica "La caja de Pandora. El sujeto político indígena en la construcción del orden liberal”, Historia Contemporánea, ${ }^{\circ}$ 33, 2006, pp. 606-608.

14 Ibidem, p. 608.

15 Las exploraciones hechas en los archivos nos sugieren que los datos existentes, aún más si se recurre al "método indiciario" al modo de Ginzburg, pueden arrojar consistentes luces a estas cuestiones. 
de Tojo, desde la constitución de las mismas en la etapa colonial hasta su desarticulación en el siglo XIX.16 La construcción de esa historia transita la composición y descomposición de las comunidades indígenas, la articulación y desarticulación de los mercados mineros regionales, fluctuaciones demográficas, los ciclos productivos, coyunturas bélicas, etc.

Madrazo al detenerse en la etapa republicana muestra la convulsionada situación de la Puna en las décadas previas a que irrumpiera con fuerza en el tablero de los conflictos la lucha por la tierra, candente desde 1872. En esas páginas dibuja un escenario donde todavía hasta los años veinte del siglo XIX subsistía con vigor la "comunidad étnica", la que se fue deteriorando por un cúmulo de factores. Entre ellos pasa revista a los efectos de la incorporación de extraños (foráneos) a las pueblos indígenas, la desestructuración de las instituciones indígenas con medidas que se fueron adoptado desde 1825 (como los cacicazgos y las tierras de comunidad), la creación de nuevas funciones administrativas e instituciones liberales del Estado republicano y, con ello, la afirmación de clanes familiares de terratenientes o comerciantes que se incrustaron en los resortes del poder local como dueños de las "funciones públicas”, la incidencia de un nuevo paquete impositivo, la constitución de nuevos poblados mestizos y la gravitación de nuevos actores.

Nos interesa detenernos en dos de estos enunciados que tienen que ver con la presencia del Estado liberal en la región. Por un lado, la gravitación del fisco provincial y también nacional pernicioso para las prácticas y basamentos de la economía indígena. La contribución territorial desde 1854, que solo pagaban los propietarios, se trasladó a los precios de arriendo que debían afrontar los campesinos indígenas. La contribución mobiliaria desde 1863 que reemplazó al diezmo por cuyo objeto se cometieron abusos y arbitrariedades contra esos sectores. El impuesto a la extracción de sal que incidió sobre un recurso explotado por los habitantes de la Puna desde época prehispánica para sostener la práctica del trueque. La nacionalización de la aduana por la que se impuso cargas a varios productos de intercambio y comercio que se mantenía con Bolivia. Madrazo puntualiza el desarrollo de un malestar generalizado por

16 MADRAZO, Guillermo, Hacienda y encomienda en los Andes. La Puna de Jujuy bajo el marquesado de Tojo, siglos XVII-XIX, Buenos Aires, Fondo Editorial, 1982. 
"la cuestión fiscal" que fue motivo de manifestaciones de descontento y "explosiones de rebeldía", como el Saqueo a la aduana de Yavi el 15 de diciembre de $1856 .{ }^{17}$

En segundo término, Madrazo hace un inventario de los principales hitos de la nueva institucionalidad republicana:

\begin{abstract}
"Desde el comienzo de la Revolución hubo un subdelegado en la Puna que dependía del gobierno salteño con funciones administrativas y ejecutivas, y debían existir ya jueces de campaña no letrados. Al separarse Jujuy de Salta se recrearon esos cargos casi simultáneamente con la extinción los cabildos, el 12 de diciembre de 1840 se dio por decreto un nuevo reglamento para la designación de jueces no letrados en la capital y el campo (jefe político, suplente y tenientes, todos ellos casi siempre lugareños mestizos o criollos). El 21 de diciembre de 1843, la legislatura restableció por ley al subdelegado para los cuatros departamentos puneños. El 14 de mayo de 1863 se crearon los cargos de comisario en toda la provincia y, al año siguiente, el 25 de enero el Juzgado de Primera Instancia de la Puna con asiento en Yavi. La Guardia Nacional [...] fue establecida en la Puna el 18 de marzo de 1867. Desde la década de1850 hay que mencionar también la presencia incipiente de las escuelas". 18
\end{abstract}

Estos importantes eslabones de la vinculación entre las poblaciones indígenas de la Puna y la instauración del nuevo orden están presentados en el estudio de Madrazo. Para él, estos hechos se enmarcan en un sendero más amplio de desestructuración del "modo productivo de comunidad" y la descomposición de la sociedad étnica en la región. Sostiene que la incipiente institucionalidad republica devino en un "mecanismo de reemplazo" en las relaciones con la sociedad indígena y que todo este avance institucional no significó la integración de los indígenas a la sociedad nacional. ${ }^{19}$ Reconoce claramente que la propiedad de la tierra, la renta y las cargas fiscales motorizaron el eje de los conflictos y reclamos en la Puna, pero pondera las respuestas más en términos de levantamientos -salvo los relatos de reclamos que incorpora como evidencias de la irritación- contra lugares de fiscalización pública (aduana y receptoría) y los recaudadores en general.

Otra visita obligada de consulta en la historiografía regional son las investigaciones de Gustavo Paz. El autor retoma y completa el esquema de instituciones planteadas por Madrazo por las que se efectiviza la presencia del

\footnotetext{
${ }_{17}$ En esta ocasión 30 indígenas tomaron y asaltaron con uso de armas la receptoría de la aduana de Yavi, llevándose consigo pertenencias de la repartición.

${ }_{18}$ MADRAZO, Guillermo, ob. cit. p. 149.

19 Ibidem.
} 
Estado provincial hacia mediados del siglo XIX en la Puna. ${ }^{20}$ Ofrece un cuadro se situaciones de conflicto muy similar, cuyos ejes centrales eran la recaudación de arriendos y contribución mobiliar, las multas excesivas y los atropellos de las autoridades locales. Pero amplía profundamente el margen acción -y reacciónindígena. Así, desentraña una serie de comportamientos prevalecientes en las décadas de 1850 y 1860 adoptando la clave interpretativa de la "acomodación resistente" de Stern, extendiendo el espectro de las formas de acción y reconociendo en ellas un margen de decisión, de participación y dinamismo por parte de los sectores campesinos arrendatarios frente al peso estructural de algunos procesos. ${ }^{21}$

Paz se detiene particularmente en la serie de reclamos formulados como peticiones al "Gobernador", en su carácter de superior autoridad e instancia posible de prestar atención a las demandas; en vez de recurrir a la justicia a la que pocas veces apelaron "[...] Tal vez por la dificultad de acceder a los tribunales judiciales, los campesinos recurrieron en varias oportunidades a la violencia directa en forma de motines contra las autoridades locales". ${ }^{22}$

\section{Ordenando la justicia en la provincia. ¿Por qué se crea el Juzgado de Primera Instancia de la Puna?}

A partir de la consecución de la autonomía política de Jujuy en $1834^{23}$ se fueron gestando las nuevas instituciones republicanas, entre ellas las encargadas de la justicia. Se trató de un proceso gradual con modificaciones paulatinas a las formas vigentes a fines de la etapa colonial.

\footnotetext{
${ }^{20}$ Añade en la lista las comisiones municipales.

${ }^{21}$ Paz reseña actos individuales como la "lentitud a la obediencia", o la "sagacidad" frente al cobro de obligaciones fiscales; y otros colectivos como la serie de peticiones efectuadas a la autoridades locales y provinciales, y las engloba como parte de sus manifestaciones frente a lo que consideraban injusto o violento, propone el concepto de Stern para entenderlas como un amplio conjunto de estrategias "por medio de las cuales el campesino intenta -y en ciertas oportunidades lo logra- modificar o mejorar con acciones continuas [...] su relación con los otros sectores de la sociedad". PAZ, Gustavo, "Resistencia y rebelión campesina en la Puna de Jujuy, 1850-1875", Boletín del Instituto de Historia Argentina y Americana "Dr. Emilio Ravignani", Tercera serie, $n^{\circ} 4,2^{\circ}$ semestre 1991, pp. 71-72.

22 Ibidem, p. 74.

${ }^{23}$ La ciudad de Jujuy y su campaña formaba de la Intendencia de Salta del Tucumán desde las reformas jurisdiccionales introducidas por los Borbones. El proceso de disgregación en provincias de esta intendencia se desencadenó con la Revolución por la Independencia siendo Jujuy la última en constituirse como tal al separarse de Salta en 1834.
} 
Así, el Cabildo capitalino prolongó sus funciones judiciales hasta fines de la década de 1830. En 1839 se sancionó el segundo ordenamiento constitucional, el Estatuto Provincial, en el que la normativa judicial todavía seguía en impasse hasta tanto "se pueda arribar a la formación del Poder judiciario en toda su perfección”. ${ }^{24}$ La administración de la justicia quedaba a cargo de una pareja de jueces, de primera y segunda nominación, para causas civiles y criminales; y preveía la constitución de "tribunales eventuales" en caso de apelación. En los departamentos de campaña la función judicial estaba fusionada con otras en la figura unipersonal de los jefes políticos, existiendo uno por cada cabecera departamental. Este era un cargo elegible para lo cual se requería la vecindad, la ciudadanía en ejercicio, una edad mínima de 30 años, "conocida probidad y adhesión a la provincia” y ser propietario de inmuebles por valores superiores a 500 pesos. En recorte censitario era muy sensible en una provincia donde había fuerte concentración de la propiedad. ${ }^{25}$ Siguiendo el registro inmueble más cercano en fecha, de 1855, esa cláusula abría el juego a los pobladores de ciertos departamentos; el de los Valles Centrales (Rectoral y Perico) donde junto a las haciendas existían medianas propiedades, y la Quebrada de Humahuaca, una región que por medio de la aplicación de la enfiteusis sobre las ex tierras de comunidad indígena había generado un universo importante de pequeños propietarios. Pero mutilaba en esta representación del jefe político a poblaciones enteras como en los cuatro departamentos de la Puna.

Siete años después (1847) se decretó un reglamento específico para organizar la justicia de Jujuy. ${ }^{26}$ Entonces comenzó a cobrar una forma más estable que se prolongó, con mínimas modificaciones, por varias décadas. Se derogó el "tribunal eventual” que fue reemplazado por "Tribunal supremo", máximo órgano jerárquico, compuesto por tres jueces "ciudadanos de capacidad". La estructura se completó con un "Juez de alzada" letrado

24 REGISTRO OFICIAL, Compilación de Leyes y decretos de la Provincia de Jujuy, desde el año 1835 hasta el de 1884, Tomo 1, Jujuy, Publicación Oficial, 1885, pp. 106- 107.

25 PAZ, Gustavo, "Gran propiedad y grandes propietarios en Jujuy a mediados del siglo XIX", Cuadernos, FHyCS-UNJu, no 21, 2003, pp. 11-22.

26 REGISTRO OFICIAL, Compilación de Leyes y decretos de la Provincia de Jujuy, desde el año 1835 hasta el de 1884, Tomo 2, Jujuy, Publicación Oficial, 1885, pp. 213-214. 
("profesor en derecho"), fiscal, defensor de pobres y procurador general. Se introdujo además un juzgado de primera instancia. Todos estos cargos eran anuales y un apéndice del gobierno de turno, puesto que eran electos y nombrados por el Poder Ejecutivo. Esa mecánica se aplicó también para los cuatro alcaldes de barrio del departamento rectoral y los "jueces departamentales", separándose en la ley la función judicial de las otras que hasta ahora reunían algunos agentes en la campaña y anulando la norma de elección de 1839 antes comentada.

El siguiente estadio de importancia en el organigrama judicial sucedió en 1851. Por un lado, ese año se reglamentó en el "Estatuto Provisorio para la Administración de la provincia" 27 la condición de ciudadanía: recayendo sobre los hombres libres nacidos en la provincia con 21 años, de otra con dos años de residencia en Jujuy, que profesen alguna industria, ciencia o arte, sin sujeción a otra clase de servicios domésticos. Señala que los derechos de ciudadanía se suspendían por deuda fraudulenta, deudor al tesoro público, ser criado a sueldo, peón jornalero, soldado de línea, vago, procesado por causa. De hecho esta normativa seguía a pie de la letra la expedida en las Cortes de Cádiz implicando, como marca Quijada, una gran amplitud para el ejercicio de la ciudadanía que integraba también a los indígenas. ${ }^{28}$

Por otro lado, se sancionó un nuevo reglamento de justicia el 30 de marzo de 1851.29 A las figuras ya establecida del Supremo tribunal de Justicia, el juez de alzada letrado, los cuatro jueces de barrio para el departamento Rectoral y los jueces departamentales (también llamado Jefe Departamental, uno por cada departamento), se van a introducir dos innovaciones claves. Primero, las condiciones para el acceso a juez de barrio y/o jefe departamental: ser ciudadano tener propiedad o medios de conocidos de subsistir decentemente, 25 años, de "buena opinión y fama". Se reafirma la base censitaria. Segundo, la creación de un nuevo juzgado de primera instancia -además del de la Capital provincial- para la Puna, con jurisdicción sobre Rinconada, Yavi, Cochinoca y

\footnotetext{
${ }^{27}$ REGISTRO OFICIAL, Compilación de Leyes y decretos..., ob. cit., Tomo 2, p. 290.

${ }^{28}$ QUIJADA, Mónica, ob. cit., pp. 611 y 615.

29 REGISTRO OFICIAL, Compilación de Leyes y decretos..., ob. cit., Tomo 2, pp. 300-315.
} 
Santa Catalina, imponiéndose las mismas condiciones para calificar como sujeto elegible que las de jueces departamentales.

El paquete se completó con la Ley de elecciones de empleados del cuerpo judicial, $3^{\circ}$ por la cual esa atribución pasó ahora a un órgano elector específico para el ámbito de la justicia, integrado por los tres jueces del Tribunal Superior, los jueces de primera instancia y un procurador general del crimen, anualmente y cada 15 de diciembre, en reunión en la Ciudad y por votación nominal. La responsabilidad de la elección de los jueces menores de la ciudad y la campaña se desprendía entonces del perímetro político del gobernador de turno y se alejaba del ámbito del pueblo donde debía ejercer sus funciones.

Al tratarse el artículo de creación del juzgado de primera instancia en la legislatura provincial se suscitó un interesante debate. ${ }^{31} \mathrm{El}$ punto en cuestión fue la clausula provisoria por la que se atribuía al Subdelegado de la Puna las funciones del juez de primera instancia en atención a las limitaciones presupuestarias del momento. Allí quedó plasmado, era imperioso el establecimiento del juzgado debido a su numerosa población y distancia, aún cuando momentáneamente recayera en el Subdelegado, porque "el antiguo régimen de las sentencias los jefes políticos había que hacer una apelación al Juez de Alzada lo que era un inconveniente y perjuicio a los gastos por la distancia [...]", llevando a la situación de que "no muchas veces prefieren esos infelices abandonar sus acciones y derechos y para remediar este mal era necesario el Juzgado de Primera Instancia”.

Pero además, se buscaba corregir un defecto que en la marcha de la organización de la justicia los Subdelegados podían subsanar. En este razonamiento, el argumento presentado fue que por conocimiento propio de algunos intervinientes en el debate, debido a su larga permanencia en la zona, sabían que antes de las modificaciones introducidas en 1847 los subdelegados de la Puna conocían en demandas judiciales, atribuciones que se redujeron con la introducción de la administración de la justicia en manos de los "Jefes

30 Ibidem, pp. 316-317.

${ }^{31}$ Archivo Histórico de la Legislatura de Jujuy, Argentina (en adelante AHLJ), Actas de Sesiones, Libro 23, sesión del 1/2/1851, Fs. 280 y siguientes. 
políticos”. Sin embargo, el subdelegado era testigo consciente de las arbitrariedades - "picardías" quedó registrado en las actas de la sesión- que a diario cometían esos jueces, sin facultad alguna para remediarlo. Entonces, el Juez de Primera Instancia de la Puna, transitoriamente desempeñado por el subdelegado, también se pergeñó como un mecanismo de control a los desbordes en la justicia de este territorio. ${ }^{2}$

Hasta acá los términos de este debate que nos posiciona en las motivaciones que rodearon la creación de este juzgado de la Puna. Entonces, es en las disposiciones de 1851 que encontramos los primeros antecedentes de la institución. En esta dirección argumentativa se manifestó una y otra vez la palabra de los vecinos de la Puna según lo testimonia la abundante correspondencia dirigida al gobierno central en esos años. Una de las imágenes más elocuentes quedó expuesta en esta misiva:

\begin{abstract}
"Con profundo dolor se ven las injustas resoluciones de los juzgados paz de la puna [...] (años ha) abusando del destino con el que ha sido seguido distinguidos, los actos administrativos terminan con escandaloso monopolio o beneficio particular, los juicios verbales son ventilados por facciones mezquinas y caprichosas sin conocer la causa ni revisarla a prueba (sic): este mismo juicio es sin figura ni forma que eccije (sic) este serio desempeño con clásico abuso de la gran carta fundamental de la constitucional y las demás forma, las que son pisoteadas [...] ¿cuál pues la apelación de tanto infeliz? Es muy claro el recurso a la Capital ¿Y cuáles los inconvenientes de todo género que sirven de muralla para ocurrir más de setenta leguas la apelación de las injusticias que se reciben? Mil.
\end{abstract}

\footnotetext{
$3^{2}$ La figura de subdelegado de la Puna se introdujo en 1843, como una autoridad excepcional para la región, tenía jurisdicción en los cuatro departamentos, con una duración de dos años y a nombramiento del poder ejecutivo provincial. Se instituía como una jefatura máxima para vigilar la administración de los jefes políticos, cumplía también funciones militares (a cargo del piquete en la zona), asimismo podía decretar políticas propias para el "adelanto" de la Puna (REGISTRO OFICIAL, Compilación de Leyes y decretos, ob. cit., Tomo 1, pp. 173 y 189). En los inicios de la etapa colonial este territorio contó con un régimen de corregidores a fin de controlar a los indígenas encomendados y fomentar y administrar la minería. Luego, fueron reemplazados por el Teniente Gobernador y Justicia Mayor quienes siguieron siendo nombrados por el Gobernador pero con intermediación del cabildo capitalino jujeño. Este ordenamiento especial obedecía a la distancia y el carácter de frontera de la Puna así como a su importancia minera, condiciones que obligaron a los capitulares jujeños a buscar la forma de ejercer poder sobre la zona (meta que no siempre se logró porque los tenientes gobernadores devinieron en algunos casos en un poder autónomo de la Ciudad). (BECERRA, María Florencia; ESTRUCH, Dolores, "Alcaldes de mina, capitulares, cateadores y mineros. Una reflexión sobre la administración de la justicia en las causas mineras de la Puna de Jujuy (siglo XVII)", Revista de Historia del Derecho, Instituto de Investigaciones de Historia del Derecho, $\mathrm{n}^{\circ} 42$, julio-dic. 2011, pp. 1-21). Para el siglo XVIII, una vez producidas las reformas borbónicas, esa figura de gobierno especial en la Puna se ejerció a través de los llamados subdelegados. Autoridad interrumpida luego de la Independencia se reformuló hacia la década de 1840. (ARAMENDI, Bárbara, "El distrito de la Puna y su primer subdelegado. Intendencia de Salta del Tucumán, 1784- 1795", Fronteras de la Historia, Instituto Colombiano de Antropología e Historia, vol. 22, $\mathrm{n}^{\circ} 1,2017$, pp. 12-37.
} 
En cuyo mérito es de imperiosa necesidad que ese ilustre gobierno tenga consideración y mirando con deferencia, a la primera necesidad de la Puna, se digne reclamar ante la HSR provincial, un juez de primera instancia que imperiosamente lo necesitan los departamentos de la Puna: el único medio y el principal punto de salvamento de los naufragios que constantemente sufren los habitantes de ella.

Se espera prudentemente que ese gobierno tan republicano amante del progreso rápido de su país, un lisonjero resultado a este respecto: le será muy fácil hacer sus canales y su influencia ante el cuerpo legislativo provincial [...]".33

El asunto volvió a retomarse recién en 1859, procurándose ya apartar la función del subdelegado de la Puna. Como intercedía en este asunto la falta de fondos públicos, el tema reapareció al proponerse la ley de presupuesto general para el año 1859-1860, donde quedó plasmado el anhelo por constituir el juzgado y se dibujó una partida de 1.360 pesos bolivianos con ese destino.34

Pese a existir la voluntad interpretamos que el Juzgado de Primera Instancia de la Puna no se hizo efectivo en ese año, no hubo nombramiento del juez y desapareció del presupuesto el detalle de cualquier asignación por la estrechez de los recursos, cuyos recortes recayeron también en otros ámbitos de la administración pública. 35

Atravesando ya la década de 1860, la misma se revela a la mirada del investigador como una etapa de una intensa y compleja convulsa social. En su transcurso el Estado provincial oscilo entre agudizar el control social en la campaña y optimizar su presencia y poder frente a las autoridades que en ella actuaban. Dentro de su idiosincrasia el gobierno proclamó como principales vicios de los pobladores "la embriagades", el robo y “el juego", legislando para aumentar las atribuciones de los comisarios y jueces de paz para condenarlos. $\mathrm{Y}$ se extendió una red de comisarios, argumentando que la medida nacía del incumplimiento de las órdenes y medidas dictadas por parte de los funcionarios públicos, apuntando a la inoperancia y deficiencia de los jueces departamentales y la “desmoralización” general reinante. 36

\footnotetext{
33 AHJ, Caja Documento año 1857, Santa Catalina, 30 de junio de 1857.

34 AHLJ, Caja Documentos, Correspondencia del Gobernador a la Legislatura, 31 de enero de 1859.

35 En vistas de estas dificultades circuló la versión de dotar igualmente de un Juez de Primera Instancia entre vecinos voluntarios de este servicio en forma gratuita. AHJ. Argentina, Caja Documento 1858, Rinconada, 29 de octubre de 1858.

${ }^{36}$ REGISTRO OFICIAL, Compilación de Leyes y decretos..., ob. cit., Tomo 2, pp. 356-358.
} 
Complementaria de esa política que, como dijimos, fluctuaba entre aumentar la vigilancia social de la población de la campaña y controlar las arbitrariedades de sus funcionarios, en el año 1864 se reflotó el proyecto de creación del Juzgado de Primera Instancia en la Puna, ocasión en que se pudo finalmente poner en funcionamiento. El desafío legislativo fue llenar los vacíos y vicios de forma que contenía la ley antecesora de 1859.37 Así, en la letra de la nueva ley se fijó sede en el pueblo de Yavi, se establecieron los sueldos del todo el cuerpo de funcionarios del Juzgado, se instituyó la figura de un fiscal que sería defensor de pobres y menores, un escribiente y un alguacil, más los gastos de funcionamiento fijados en el presupuesto anual. La elección y nombramiento quedaba reservada al Superior Tribunal de Justicia. ${ }^{8}$

Aunque como detallaremos en el siguiente apartado este juzgado solo funcionó poco más de un año, la Constitución Provincial de 186639 lo reconoció como parte de su estructura judicial, aunque delegaba su nombramiento al Poder Ejecutivo y establecía, además de la ciudadanía en ejercicio y la mayoría de edad, la calificación de letrado. Se delegaba en la figura del juez de primera instancia de la Puna la facultad para tramitación de causas civiles y criminales, para ser instancia de apelación de las sentencias de los jueces de paz y para conocer reclamos y vigilar a jueces de paz y comisarios. Más allá de las cláusulas referentes a los juzgados de primera instancia, esta reforma constitucional introdujo una variación importante al confiar a un organismo local de gobierno, representado en la Municipalidad, la propuesta de los jueces de paz. $4^{40}$

\footnotetext{
37 AHLJ, Argentina, Actas de sesiones, libro 10, sesión del 22 de enero de 1864, fs. 154.

${ }^{38}$ REGISTRO OFICIAL, Compilación de Leyes y decretos..., ob. cit., Tomo 2, pp. 370-371.

39 Ibidem, pp. 463-465.

$40 \mathrm{El}$ nivel de gobierno municipal quedó establecido por ley en Jujuy en 1858. El recorrido documental por las décadas de 1860 y 1870 testimonian una serie de dificultades para la puesta en funcionamiento, y dejan traslucir la existencia de un poder local que ofrecía bancadas para el vecino común -además de las destinadas a los "miembros natos"- y acogía, escuchaba y accionaba las peticiones de los sectores más débiles de su jurisdicción. La temática es un campo de investigación muy rico que no incluimos en este análisis. Sobre el asunto la historiografía de América Latina, especialmente la mexicana, ha producido abundantes referencias en la que, en general, se remarca cómo a través de este gobierno-institución se transfirieron cuotas del poder político central a las localidades y se reordenaron socialmente los principales resortes del poder permitiendo a una mayoría de ciudadanos comunes de mediano y bajo status su efectiva presencia pública. De manera muy especial con la expansión del sistema de ayuntamientos desde las Cortes de Cádiz se habilitó "el camino para la incorporación de las comunidades indígenas en un orden político que atravesaba las fronteras étnicas; y los indios asumieron con rapidez la nueva terminología y el conocimiento de aquellos aspectos de la constitución de Cádiz que les afectaban directamente". QUIJADA, Mónica, ob. cit. p. 615.
} 
Para cuando se produjo la reapertura del Juzgado de Primera Instancia de la Puna en 1870, por tres meses más, seguía siendo urgente atender con esta medida al "clamor" general de los pueblos de la Puna, ahora agudizado por la “desmoralización causada por los jefes de las montoneras” de Felipe Varela. ${ }^{41}$

Los vecinos de la Puna buscaron los canales más directos para asentar de nuevo la urgencia y necesidad de este juzgado:

\begin{abstract}
"Sabido es que la distancia tan lata de los departamentos de la puna con esa capital donde reside el juzgado competente, es la causa para muchos derechos sagrados sean auguados (sic) bajo la férula de los hechos. Especialmente los de aquella pobre e ignorante gente, a quienes como a los demás las leyes protegen y conceden las mismas garantías, pero desgraciadamente no se consigue este mismo apoyo, en los funcionarios públicos de la campaña, ora porque estos carezcan de conocimientos suficientes, ora porque media alguna mesquina (sic) personalidad u otro incidente por el estilo que con bastante repetición se lamentan en estos departamentos [...] Es a todo necesario establecer un juzgado superior en esta para coartar los abusos frecuentes que se cometen y remediar al mismo tiempo muchos y muchísimos males. Que mayor bien se puede procurar para un pueblo que la buena administración de justicia?”.42
\end{abstract}

Aún perdurando en la letra del diseño legal de organización de la justicia provincial de 1872, la existencia del Juzgado de la Puna no volvió a ser realidad después de la última experiencia. Devinieron luego los años del cruento conflicto por las tierras de Casabindo y Cochinoca y de toda la región de las tierras altas, en 1874 se pronunció en forma definitiva su clausura, trasladando los asuntos correspondientes desde la jurisdicción de la Puna al de la Capital.43

\title{
El Juzgado en acción: autoridades, actuaciones, significados
}

${ }^{41}$ REGISTRO OFICIAL, Compilación de Leyes y decretos de la Provincia de Jujuy, desde el año 1835 hasta el de 1884, Tomo 3, Jujuy, Publicación Oficial, 1885, 31 de julio de 1867, p. 62. Aunque el discurso del que se valió el gobierno denota una posición ideológica clave para explicar las circunstancias reinantes, cuando habla de desmoralización y atribuye al movimiento varelista el carácter de una "montonera", lo real es que la provincia y especialmente el área puneña fronteriza con Bolivia se manutuvo en vilo por este conflicto -con territorios ocupados sobre todo el pueblo de Humahuaca y de Yavi-, permanentes movilizaciones de las guardias nacionales, contribuciones de todo tipo para el sostenimiento de ambas fuerzas, procesamientos a militares por deserción y a civiles que siguieron la causa varelista, amotinamientos y manifestaciones de diverso tipo- desde el mes de agosto de 1867 hasta el mes de enero de 1869. FANDOS, Cecilia, "La campaña de Jujuy entre la Guerra del Paraguay y el levantamiento de Varela. Principales manifestaciones socioeconómicas en la Quebrada de Humahuaca y Puna”, II Reunión Tendencias y Debates en Historia Económica Argentina: Coyunturas de crisis económica desde la perspectiva regional-provincial en la Argentina de los siglos XIX a XXI, San Salvador de Jujuy, 19 y 20 de octubre 2017.

42 AHJ, Caja Documento, año 1869, Yavi, 17 de abril de 1869.

43 REGISTRO OFICIAL, Compilación de Leyes y decretos..., ob. cit., Tomo 3, p. 224. 
El Juzgado de Primera Instancia de la Puna funcionó entre los meses de junio de 1864 y agosto de 1865 y diciembre de 1870- marzo de 1871. En la primera etapa fue juez principal un vecino y rico propietario de Rinconada, Pedro Nolazco Baldiviezo, dueño de la importante hacienda de San José de Rinconada. Para la segunda etapa la envestidura recayó en Matías Abila, quién reunía el requisito de ser letrado.

Pese al poco tiempo de vida fue de notable intensidad y significación la tarea que desempeñó. Por un lado, como autoridad superior en la Puna, era obligatorio para estos jueces recorrer cada distrito para supervisar y aconsejar. El Juez Baldiviezo emprendió ese cometido en octubre de 1864 ocasión en que desarrollo una ardua labor en el conflictivo departamento de Cochinoca. Así intervino, por ejemplo, mediando en un debate desatado en la municipalidad de esa localidad para aclarar y encauzar la inversión de los fondos aportados por la feligresía para las obras de reparación de la Iglesia del pueblo. 44 Como resultado, al salirse de Cochinoca había logrado formar una comisión directiva para continuar la obra clarificando los montos de la inversión.

Por otro lado, en el primer tramo de vida del juzgado, en un año de actuación se tramitaron 34 causas, 20 de materia criminal y 14 civiles. Hemos transcripto y clasificado las mismas en el Cuadro 1 que sigue. Luego, detallamos las del segundo tramo del juzgado en el Cuadro 2.

\footnotetext{
$44 \mathrm{Al}$ respecto señaló: "[...] llevo ocho días en este pueblo para conocer de los fondos con que cuenta la iglesia parroquial para su reconstrucción. Sin embargo de los egresos que ha tenido este municipio destinados a ese objeto y recaudados antes de ahora permanecen hasta hoy cubiertos con un misterioso velo que no se ha podido penetrar, tengo la esperanza de que yo lo haré. No lo veo tan difícil viendo la buena predisposición de muchos feligreses. Falta impulsar esta voluntad con un centro de acción que de movimiento y actividad a la empresa [...] restableciendo con el mismo objeto las funciones de la municipalidad que desgraciadamente no llena los deberes”. AHJ, Caja Documento, año 1864, Cochinoca, 9 de septiembre de 1864.
} 


\section{Cuadro 1.}

Causas tramitadas en el Juzgado de Primera Instancia de la Puna. Junio de 1864-junio de 1865

\begin{tabular}{|c|c|c|c|c|}
\hline Fuero & Causa & Dem andado & Dem andante & Situación \\
\hline Criminal & \begin{tabular}{|l|} 
Abuso de \\
autoridad \\
\end{tabular} & Mariano Burgos & & Sentencia \\
\hline Criminal & \begin{tabular}{|l|} 
Abuso de \\
autoridad \\
\end{tabular} & Bartolomé Aramayo & Luis Ríos & Sumariado \\
\hline Criminal & \begin{tabular}{|l|} 
Abuso de \\
autoridad
\end{tabular} & Bartolomé Aramayo & José María Farfán & Orden de citación \\
\hline Criminal & Agravios & José Bruno Churquina & Castel Fort Marín & Sentencia \\
\hline Criminal & Agravios & Federico Surita & Luis Ríos & Sentencia \\
\hline Criminal & Agravios & Pedro y Carlos Gardel & Eulalia Rodríguez & Conciliación \\
\hline Criminal & Agravios & Mariano Alanica & Guillermo Garzón & Conciliación \\
\hline Criminal & Agravios & Sista Tejerina de Múrua & Dorotea Córdoba & Conciliación \\
\hline Civil & $\begin{array}{l}\text { Apelación contra } \\
\text { juez de Paz }\end{array}$ & Mariano Burgos & Feliz Flores & Sentencia \\
\hline Civil & $\begin{array}{l}\text { Apelación contra } \\
\text { juez de Paz }\end{array}$ & Mariano Burgos & Bruno Vargas & Sentencia \\
\hline Criminal & Asesinato & Evaristo Martínez & & Juicio sumario \\
\hline Criminal & Asesinato & Eucebio Carlos & & Sentencia \\
\hline Civil & Deuda & José Guatar & \begin{tabular}{|l|} 
Escolástica Gareca de \\
Carrazco \\
\end{tabular} & Sentencia \\
\hline Civil & Deuda & José María Gonza & Manuel Romero & \begin{tabular}{|l|} 
Transada \\
\end{tabular} \\
\hline Civil & Deuda & Estanislao Choque & Alejandro Mamaní & Conciliación \\
\hline Civil & Deuda & Tomasa Cáseres & José Falcon & Embargo de bienes \\
\hline Civil & Deuda & Ignacio Wayar & Navea y Ccia. & Conciliación \\
\hline Civil & Deuda & Cesario Echenique & \begin{tabular}{|l|} 
Sipriano Echenique \\
\end{tabular} & \begin{tabular}{|l|} 
Conciliación \\
\end{tabular} \\
\hline Civil & Deuda por tutela & Aniceto Calisaya & Aniceto Calisaya & \\
\hline Criminal & Herida & Justo Trujillo & Narciso García & Sentencia \\
\hline Criminal & Herida & Marcelino Calisaya & Juan de la Cruz Valdez & Sentencia \\
\hline Criminal & Herida & Vitoriano Arjona & Juan de Dios Alberto & Sumariado \\
\hline Civil & $\begin{array}{l}\text { Incumplimiento de } \\
\text { contrato de } \\
\text { arriendo }\end{array}$ & $\begin{array}{l}\text { Nicolas Apaza y } \\
\text { Alejandro Checa }\end{array}$ & José Bruno Churquina & Sentencia \\
\hline Civil & $\begin{array}{l}\text { Indemnización por } \\
\text { perjuicios }\end{array}$ & \begin{tabular}{|l|} 
Feliz Mamani y \\
Reimundo Molleja
\end{tabular} & José Feliz Ontiveros & Citadas las partes \\
\hline Criminal & Injurias & Candelario Mamani & José Manuel Apaza & Conciliación \\
\hline Criminal & \begin{tabular}{|l} 
Insulto al juez de \\
paz
\end{tabular} & Reimundo Cari & & Sentencia \\
\hline Criminal & $\begin{array}{l}\text { Invasión a la } \\
\text { receptoría de las } \\
\text { Salinas } \\
\end{array}$ & $\begin{array}{l}\text { José M Antolín y } \\
\text { Nicodemos López }\end{array}$ & $\begin{array}{l}\text { José Feliz Alvarez } \\
\text { Prado }\end{array}$ & Sumariado \\
\hline Civil & $\begin{array}{l}\begin{array}{l}\text { Liquidación de } \\
\text { cuentas }\end{array} \\
\end{array}$ & Joaquin Mercado & Bernardo Balderrama & Suspendido \\
\hline Civil & \begin{tabular}{|l|}
$\begin{array}{l}\text { Liquidación de } \\
\text { cuentas remate sal }\end{array}$ \\
\end{tabular} & $\begin{array}{l}\text { José Féliz Alvarez } \\
\text { Prado }\end{array}$ & Melchor Muñóz & En trámite \\
\hline Criminal & Maltrato a menor & Calisto Barconte & Fernanda E de Gonza & Conciliación \\
\hline Criminal & $\begin{array}{l}\text { Muerte } \\
\text { involuntaria }\end{array}$ & Feliciana León & & \\
\hline Criminal & \begin{tabular}{|l|} 
Parricidio \\
\end{tabular} & Jose Manuel Yurquina & & Sentencia \\
\hline Criminal & Parricidio & Pastor Tastaca & & Sentencia \\
\hline Civil & $\begin{array}{l}\text { Posesión de una } \\
\text { casa }\end{array}$ & Juliana Senarra & $\begin{array}{l}\text { Escolástica Gareca de } \\
\text { Carrazco }\end{array}$ & Sentencia \\
\hline
\end{tabular}




\section{Cuadro 2}

Inventario de causas del Juzgado de Primera Instancia de la Puna. Diciembre 1870-marzo de 1871

\begin{tabular}{|l|l|l|l|l|}
\hline \multicolumn{1}{|c|}{ Fuero } & \multicolumn{1}{|c|}{ Cau sa } & \multicolumn{1}{c|}{ Dem andado } & \multicolumn{1}{c|}{ Dem andante } & \multicolumn{1}{c|}{ Situación } \\
\hline Criminal & $\begin{array}{l}\text { Abuso de } \\
\text { autoridad prisión } \\
\text { indebida }\end{array}$ & $\begin{array}{l}\text { Fortunato Sotelo por } \\
\text { orden de Comisario } \\
\text { de Yavi }\end{array}$ & Eucebio Wayar & Iniciada \\
\hline Criminal & $\begin{array}{l}\text { Apelación contra } \\
\text { Juez de Paz }\end{array}$ & Mariano Burgos & Pascual Gerónimo & Iniciado \\
\hline Criminal & Asesinato & Siriaco Ramos & & En trámite \\
\hline Criminal & Asesinato & Pedro Mamani & Sra. Flores (su esposa) & Resuelto \\
\hline Civil & Deuda & $\begin{array}{l}\text { Testamentaria Felipe } \\
\text { Castillo }\end{array}$ & José María Gonza & En trámite \\
\hline Criminal & Deuda por ganado & Pedro Bargas & & Iniciado \\
\hline Criminal & Estupro & Jacinto Rueda & $\begin{array}{l}\text { Testamentaria de } \\
\text { Fructoso Ramos }\end{array}$ & Resuelto \\
\hline Civil & Inventario & $\begin{array}{l}\text { Bienes de Bárbara } \\
\text { Flores }\end{array}$ & Resuelto \\
\hline Civil & Inventario & $\begin{array}{l}\text { Testamentaria de Juan } \\
\text { de Dios Morales }\end{array}$ & Iniciado \\
\hline Civil & $\begin{array}{l}\text { Inventario y } \\
\text { partición de bienes }\end{array}$ & & José María Orias & Conciliación \\
\hline Criminal & Maltrato físico & Mariano Burgos & $\begin{array}{l}\text { Testamentaria } \\
\text { Ermeneguilda Pinedo }\end{array}$ & Resuelto \\
\hline Civil & $\begin{array}{l}\text { Malversación de } \\
\text { bienes }\end{array}$ & Francisco Sajama & Resuelto \\
\hline Criminal & Robo & Ramón Ramirez & Estefanía Farfán & Resuelto \\
\hline Civil & Testamento & & Fuente: elaboración propia sobre la base de AHJ, Argentina, Caja Documento, Año 187 17 de \\
marzo de 1871 & & & \\
\hline
\end{tabular}

Nos interesa detenernos en las causas que tomaron estado público. Se trata de aquellas en las que ciudadanos litigaron contra autoridades, o viceversa. Los avisos sobre las arbitrariedades que ejecutaban estas autoridades en la Puna fueron recurrentes e impresionan hoy al lector de la documentación los detalles de los hechos y de las prácticas. Su importancia como pruebas de la explotación y los abusos que recaían sobre la masa indígena de la región, avivando variadas estrategias de resistencia, ha sido suficientemente subrayada por la literatura existente. Como veremos en las páginas que siguen, el malestar popular se canalizó igualmente por vía judicial llevando a las principales autoridades al banquillo de los acusados. Mariano Burgos, Luis Nogales, Benito Aramayo, Laureano Saravia y Facundo Wayar, como jueces de paz o como comisarios, son ejemplos de agentes procesados en esos años quienes, sin perder su cuota de 
poder en el largo plazo, fueron exonerados, suspendidos, compelidos a dimitir, embargados sus bienes $\mathrm{y}$, a veces, obligados a reponer dinero. 45

Uno de los personajes nombrados, Mariano Burgos, fue sistemáticamente y a veces en forma simultánea juez de paz, comisario y jefe de la Guardia Nacional de Yavi desde mediados de la década de 1850 y durante toda la del $60^{\prime}$. En el conjunto de las numerosas quejas elevadas por distintos actores a la municipalidad local y/o al gobierno provincial se le reportan conductas de ociosidad para con el deber público, agravios verbales y físicos, "vicios" de todo tipo, cobros fiscales indebidos, defraudación al fisco, exigencia de servicios personales, en resumidas cuentas, una "burla" permanente a los "derechos ciudadanos". ${ }^{46}$ Aunque no sabemos los detalles de las tramitaciones ante el Juzgado de Primera Instancia de la Puna más allá de la carátula que informa el juez -registradas en los Cuadros 1 y 2-, entendemos que se trató de un sujeto verdaderamente impopular cuyos comportamientos fueron percibidos por las autoridades superiores y en muchos casos fue penalizado o tuvo que resarcir sus actos. En 1864 corrió una suspensión en su función de comisario por sumario administrativo precisamente por los abusos de autoridad.47 $\mathrm{Y}$ en 1869 su situación terminó elevándose al Juez de Alzada.

Para entonces la presentación más aguda provino de la municipalidad de Yavi que como depositaria de un discurso enteramente plural, traducía el pesar colectivo sobre la "farsa" que reinaba a raíz de sus actuaciones "en nuestras instituciones y garantías de individuo".48 De oficio se le inició causa en el Juzgado de Primera Instancia de la capital, viéndose obligado a dimitir en todas sus funciones al año siguiente.

\footnotetext{
45 REGISTRO OFICIAL, Compilación de Leyes y decretos..., ob. cit., Tomo 2, p. 522; Archivo Histórico de Tribunales de Jujuy, Jujuy (en adelante AHTJ), Expediente 4730, Carpeta, 132, año 1866, Investigación y procesamiento al Comisario de Yavi; PAZ, Gustavo, "Resistencia y rebelión campesina...”, ob. cit. p. 74. No detallamos las referencias de los casos de Burgos y Aramayo porque sobre ellos nos detendremos en el análisis.

46 AHJ, Caja Documento, año 1857, Yavi, 14 de septiembre de 1857; Yavi, 24 de diciembre de 1863; Yavi, 18 de febrero de 1864; Yavi, 17 de marzo de 1864; Yavi, 30 de enero de 1868; Yavi, 17 de octubre de 1869; Yavi, 28 de octubre de 1869.

47 AHJ, Caja Documento, año 1864, Yavi, 18 de mayo de 1864.

48 AHJ, Caja Documento, año 1864, Yavi, 17 de octubre de 1869.
} 
Los momentos en que los jueces de paz/comisarios procedían a tomar declaraciones o detener un sujeto fueron motivos de alteración generalizada del orden público en la Puna. Si bien estos sucesos cotidianos eran protagonizados solo por el individuo implicado y las fuerzas de seguridad, la noticia se esparcía rápidamente en todo el vecindario activando una red de solidaridades y bandos al punto tal que el asunto de carácter personal pasaba a ser público y colectivo. 49 Aunque los agentes encargados de registrar e informar los hechos buscaban individualizar el delito, responsabilizando y calificando a sujetos concretos, a lo sumo a dos o tres, (el bandido, el vago, etc.,) se deduce del trasfondo de estos mismos relatos que detrás del individuo solía haber más actores participando y compartiendo intereses comunes.

Traemos al ruedo un caso que repercutió en toda la Puna y que fue inmediato a la puesta en funcionamiento del Juzgado de Primera Instancia de la Puna, provocando la agilización del nombramiento de sus autoridades en 1864 . Como el Asalto a la Aduana de Yavi y el Motín de la Sal de años previos, este hecho tuvo una mira propia -los conductos de la justicia- y quedó registrado como el Motín de Cochinoca contra la autoridad judicial, del 23 de febrero de 1864. En palabras del juez departamental de Cochinoca, ese día,

\footnotetext{
"me hallaba en mi juzgado desempeñando mis diarias atenciones, y me encontraba recibiendo una muy fundada y justa queja de los principales vecinos de este pueblo [...] que exponían sus quejas contra el bandido Luis Ríos hombre que según el dice no tiene autoridad a quien obedecer. En estas circunstancias se aproximo el citado Ríos a mi juzgado, mas siendo su persona azarosa y espuesta (sic), le ordene que se retirase, mas no habiendo obedecido lo conducir a la cárcel donde continuó [...] desobedeciendo [...] en estas circunstancias se presentó un grupo sedicioso de indios [...] pidiendo explicaciones y la soltura del reo, se las negué y contesté que luego lo sabrían que no era oportunidad ni deber mío satisfacerla, entonces de vos (sic) en cuello ofrecieron matarme a mí junto a los respetables vecinos".50
}

Sin haber tenido acceso a alguna voz propia en primera persona, no sabemos mucho más sobre el "bandido" Ríos y desconocemos si lideraba alguna causa pública que le mereciera la deferencia en su defensa de los sectores indígenas de Cochinoca, salvo que era un emisor activo de denuncias contra los recaudadores fiscales en las campañas locales logrando suficiente eco entre los

49 AHJ, Caja Documento, año 1859, Cochinoca, 4 de enero de 1859.

50 AHJ, Caja Documento, año 1864, Cochinoca, 24 de febrero de 1864. Caja Documento, año 1864, Cochinoca, 8 de marzo de 1864. 
vecinos. ${ }^{11}$ Ríos se escapó, pero como corría sobre toda la provincia una orden de captura se lo alcanzó en Humahuaca a los pocos días y fue remitido a la capital provincial.52

Quién tomó una particular posición en todo este asunto fue el Comisario Superior de la Puna, en una correspondencia emitida al gobernador, minimizando y relativizando la envergadura de los hechos que denunciaba el juez de paz de Cochinoca sobre la "coacción a su autoridad". Además, con la fuerza de su opinión, expuso que

\begin{abstract}
"En presencia de estos sucesos salta la previsión del gobierno de haber iniciado la erección de un Juez de Primera Instancia para los departamentos de la Puna, a fin de que la acción judicial contenga en la órvita (sic) de sus deberes a jueces y particulares, que ha distancia de la Capital y la carencia de una autoridad superior todos se extravíen".53
\end{abstract}

Casi de inmediato se arbitró el nombramiento del Juez Baldiviezo. Pero volviendo al conflicto suscitado en Cochinoca, de parte de quienes se solidarizaron con Ríos creemos que tal decisión fue sobre todo una exposición del repudio al abuso de autoridad. Nos queda claro que este acontecimiento tenía enlaces con temas candentes en el vecindario de Cochinoca, ligados a la inversión de los fondos públicos en la obra de la parroquia del pueblo, las prácticas arbitrarias en los cobros fiscales de este departamento y en la exigencia que se hacía de servicios personales justificados en la legalidad de viejas costumbres. Por uno y otro asunto la figura de Bartolomé Aramayo, el comisario de policía de este departamento en esos años, fue el foco de los litigios, también con el propio Ríos. Como se observa en las listas los Cuadros 1 y 2 fue sujeto de denuncias -y procesamiento- judiciales por abuso de autoridad.

En cuanto a las obras de la parroquia, ya en su visita al departamento el Juez Baldiviezo había dicho que sobre el asunto rondaba un "misterioso velo". Aramayo había sido tesorero en la administración de esos fondos y fue

\footnotetext{
${ }^{51}$ AHJ, Caja Documento, año 1864, Cochinoca, 20 de marzo de 1864. $5^{2}$ AHJ, Caja Documento, año 1864, Humahuaca, 9 de marzo de 1864. 53 AHJ, Caja Documento, año 1864, Yavi, 12 de marzo de 1864. El 27 de marzo del mismo año el poder ejecutivo aligeró el nombramiento del flamante juez de primera instancia para la Puna.
} 
cuestionado por varios vecinos de Cochinoca, entre ellos el propio Ríos,54 viéndose en la obligación de responder a varios pedidos de informes y justificación de las cuentas seguidas.55 Más complicada fue la sospecha que recayó sobre Aramayo como responsable de exigir obligaciones de servicios de alcaldes y alguaciles entre la población de Cochinoca, al extremo de verse involucrado en la tramitación de una causa judicial en la instancia del juez de alzada, y por un auto del mismo tener que acatar la suspensión en sus funciones de comisario por abuso de autoridad e infracción de las garantías constitucionales. 56

El tema fue avivado por un grupo que sufría la obligación de esos servicios recurriendo desde 1864 para el socorro y su consecuente exoneración al Juez de Primera Instancia de Puna en un primer momento, al Gobernador de la provincia luego en 1865, al juez de alzada en 1866.57 La puesta en práctica de estas obligaciones fue reconocida y justificada por Aramayo y otras autoridades por acomodarse a un régimen y nombramientos de alcaldes y alguaciles con suficiente antigüedad y costumbre, que tenía la venia del gobierno actual por cuanto era

\footnotetext{
"el único medio de conservar la tranquilidad y orden [...] para transmitir y hacer efectivas las disposiciones que todos los días manda cumplir el gobierno, para hacer efectivas y cumplir las disposiciones de juzgado superior [...] y por consiguiente esta autorizado y muy consentido este orden de servicio". 58
}

Efectivamente, durante la colonia el servicio personal de indios (en entidades públicas y privadas) para tareas domésticas en haciendas y estancias o parroquias y diferentes tareas administrativas requeridas por las autoridades (para la administración en las ciudades, centros mineros, tambos, entre otros) fue costumbre, teniendo continuidad con ciertas variaciones durante la República.59 Sin embargo, en todos los ordenamientos legales liberales republicanos estas prácticas fueron prohibidas. En Jujuy además de haber sido una fórmula proclamada en el texto de diversas cartas constitucionales, un

\footnotetext{
54 AHJ, Caja Documento, año 1865, Cochinoca, 10 de diciembre de 1865.

55 AHJ, Caja Documento, año 1864, Cochinoca, 18 de julio de 1864.

${ }^{6}$ REGISTRO OFICIAL, Compilación de Leyes y decretos..., ob. cit., Tomo 2, p. 524.

57 AHJ, Caja Documento, año 1865, Cochinoca, 11 de julio de 1865.

$5^{8}$ AHJ, Caja documento, año 1865, Cochinoca, 6 de noviembre de 1866.

59 CHOQUE CANQUI, Roberto, "La servidumbre andina en Bolivia", Rossana BARRAGÁN y Seemin QAYUM (dir.), El siglo XIX: Bolivia y América Latina, Lima, IFEA, 1997, pp. 437-447.
} 
decreto de 1858 reafirmó la proscripción de exigir en los departamentos de campaña, a ningún ciudadano o extranjero, servicio forzado alguno "ya sea en clase de alcalde, alguacil, ni pongo, a menos que sea voluntad de la persona y que reciba salario". ${ }^{60}$ Fue nuevamente condenado a raíz de estos conflictos que estamos tratando en la década de 1860. ${ }^{61}$ Las antiguas funciones de alcaldes y alguaciles fueron denunciadas como "servicios personales" dado su carácter forzado, gratuito (y a propia costa) y en provecho particular de los jueces de paz y comisarios, que nombraban con estos rótulos a vecinos de la campaña de Cochinoca, exigiendo un cúmulo de obligaciones que se incrementaron con el paso del tiempo;

\begin{abstract}
"traer leña, marcharse de charquis con comunicaciones [...] acompañar a los jueces cuando salían en comisiones para hacer inventarios, cobrar sus deudas y las de los vecinos del pueblo procedentes de los repartos que hacen de sus negocios [...] cobrar los derechos fiscales [...] la obligación de custodia y mantener a los presos [...] el de trabajar en la Iglesia que actualmente se fabrica, siendo de cada uno echar en su recua doce viajes de tierra [...] lo mismo que cal, leña, palos". ${ }^{62}$
\end{abstract}

Lo curioso fue que mientras las autoridades representativas de ese orden liberal se escudaron en la costumbre para disfrazar un abuso, quienes se veían forzados a cumplir con estas prestaciones demandaron a Aramayo y otros argumentando su carácter inconstitucional por violar el artículo 16 de la Constitución Provincial y el 17 de la Nacional, reclamando para sus personas el goce de los mismos derechos y garantías que los demás argentinos. ${ }^{63} \mathrm{Si}$ bien estos servicios no desaparecieron, al menos se fomentó una opinión pública condenatoria. Por toda esta actuación fue suspendido de su cargo Aramayo como infractor de las garantías constitucionales y se obligó a ratificar su prohibición mediante la sanción de un decreto en 1867.64

\footnotetext{
6o REGISTRO OFICIAL, Compilación de Leyes y decretos..., ob. cit., Tomo 2, 24 de julio de 1858, p. 172.

${ }^{61}$ REGISTRO OFICIAL, Compilación de Leyes y decretos..., ob. cit., Tomo 2, 8 de febrero de 1867, p. 495.

${ }^{62}$ AHJ, Caja documento, año 1865, Cochinoca, 11 de julio de 1865

63 Ibidem.

64 REGISTRO OFICIAL, Compilación de Leyes y decretos..., ob. cit., Tomo 2, 31 de julio de 1867, p. 495 .
} 
Finalmente, Aramayo fue sumariado administrativamente en 1864 por inadecuación a los procedimientos establecidos en las recaudaciones fiscales. ${ }^{65}$ A la vez, la oposición y resistencia del pueblo de Cochinoca a las arbitrariedades de Aramayo por el cobro de los impuestos fue llevada a conocimiento del Juez de Primera Instancia de la Puna, quién le cursó una fuerte advertencia al respecto. ${ }^{66}$ La toma de partido del Juez Baldiviezo en defensa de los avasallados dejó expuesto a Aramayo, según las propias palabras del cuestionado comisario, como un gran "abusador de la autoridad" ${ }^{67}$

\section{Palabras finales. Preludios y epílogos de la justicia en la Puna}

Hemos venido argumentando -y procurando ofrecer evidencia en voces propias- que la experiencia del Juzgado de Primera Instancia en la Puna reflejó, parafraseando a Romana Falcón, la "dialéctica del poder". ${ }^{68}$ Porque además de surgir del propósito por marcar presencia estatal a través de una institución del tipo y, por ende, ejercitar el control social sobre estas poblaciones impartiendo un modelo uniforme de justicia, ese control también se orientaba a sus propios agentes públicos en honor a la recepción y capacidad de escuchar la voz de los campesinos indígenas y a un interés genuino por sus quejas. El Juzgado de la Puna fue deseado por el pueblo de esta región y también por las esferas del gobierno, aunque tuviera fugaz presencia. Contra su persistencia obró un factor material de peso: los endebles recursos públicos.

En la raíz del Juzgado de la Puna incidieron también razones geográficas (la distancia y su situación de frontera internacional), demográficas (la región era la principal congregación poblacional y especial su composición étnica) e históricas. Efectivamente, la Puna tenía un pasado "díscolo" frente a las figuras estatales. Desde la etapa colonial, el Cabildo de Jujuy había debido lidiar con

\footnotetext{
65 Ibidem, pp. 389-390.

66 AHJ, Caja Documento, año 1865, Cochinoca, 9 de agosto de 1865.

${ }_{67}$ AHJ, Caja Documento, año 1865, Cochinoca, 8 de agosto de 1865.

${ }^{68}$ Falcón adscribe este término a su análisis de los jefes políticos de México para explicitar una concepción del dominio, el que resulta siempre relativo incluso para quienes son los más poderosos por la improbabilidad de que pueden controlar todos los resortes del poder. Por el contrario, en este modo de entender el poder es factible que diferentes agentes -aún las comunidades indígenas- puedan inscribirse en una dialéctica de apoyo y, a la vez, de rechazo, de participar en la negociación del poder. FALCON, Romana, El Jefe Político. Un dominio negociado en el mundo rural del Estado de México, 1856- 1911, México, El Colegio de México, 2015.
} 
diferentes intereses en su intento por asegurar su territorialidad. La región de la Puna fue estructuralmente costosa de torcer al reconocimiento de su autoridad:

\begin{abstract}
"la distancia, la acción de sus encomenderos, ligados a otras jurisdicciones -a Salta y posteriormente a Tarija- y su condición de zona minera le dieron una gran autonomía. Por esta última razón, en 1624 el Cabildo de Jujuy creó el cargo de Lugarteniente de Cochinoca y Casabindo, para la administración de la justicia en la región. Con posterioridad [...] nombró un Teniente Gobernador para la Puna, con sede en Rinconada del Oro y con jurisdicción sobre la población de toda la región, especialmente en los litigios por las minas y causas criminales".69
\end{abstract}

Seguramente estas instituciones coloniales eran parte de la memoria activa de quienes debían gobernar la Puna en el siglo XIX. El recuerdo y el conocimiento de ese contexto en los hombres públicos de la república liberal, nos hace pensar que el Juzgado de Primera Instancia de la Puna se sostuvo también por una línea de continuidad histórica. El juzgado situado en territorio propio, así como el restablecimiento de la figura de subdelegados, evidencian la exigencia de instituciones/autoridades especiales para esta región. La explicación radica en términos de una necesidad dadas las distancias físicas, pero también las de índole social y material para ejercer control social y la vigilancia de los abusos de los propios agentes estatales. La experiencia histórica que reconstruimos, por las razones comentadas, quizás sea una expresión de la puesta en práctica de una "justicia en proximidad". ${ }^{70}$

Por último, la justicia en un sentido amplio fue uno de los derechos peleados por los habitantes de la Puna. Aún cuando la reivindicación de ciertos derechos de propiedad pasó a constituir la primacía de la lucha, de los conflictos, de las políticas en la década de 1870 y subsiguientes, la justicia siguió siempre teniendo vigencia.

Como nos gusta, dejemos hablar a los propios sujetos. Frente la imperiosa necesidad de restaurar el “orden” en los departamentos de la Puna, en la convulsionada década de 1870, producido el levantamiento, la batalla de Quera

${ }^{69}$ SICA, Gabriela; ULLOA, Mónica, "Jujuy en la colonia. De la fundación de la Ciudad a la crisis del Orden colonial”, Ana TERUEL y Marcelo LAGOS (dir.), Jujuy en la Historia. De la colonia al siglo XX, Jujuy, EDIUNJu, 2010, p. 51.

70 "El concepto de justicia de proximidad fue empleado por la historiografía francesa para analizar prácticas judiciales que presentan uno o varios aspectos de proximidad plural"; a fin de reducir la distancia geográfica, social (por situaciones de insolvencia económica), cultural (debido a inhibiciones simbólicas) y temporal (que agilice el procedimiento y lo abarate), BARRIERA, Darío "Justicia de proximidad, pasado y presente, entre la historia y el derecho", PolHis, año 5, $\mathrm{n}^{\circ}$ 10, segundo semestre 2012, p. 54. 
y la resolución de expropiación de la finca de Casabindo y Cochinoca de las manos del poderos marqués de Yavi, el fiscal general, aconsejaba al Excelentísimo Gobernador, a propósito de una petición de los indígenas de Yavi sobre derechos de tierras, que pese a la justeza de las reclamaciones expuestas debía desestimarlas porque no era materia de su competencia sino de "tribunales competentes". Pero, al mismo tiempo,

\begin{abstract}
"este ministerio se permite añadir que [...] el establecimiento de un juzgado civil y criminal localizado cerca de la Puna, que reemplace al que anteriormente existía en Yavi, son los medios que generalmente se ha juzgado y se creen indispensables para llenar las necesidades de un buen servicio público y hacer verdaderamente efectivas las garantías constitucionales de que quizás hoy solo en parte gozan los vecinos de aquellos departamentos, desgraciadamente siempre víctimas de especulaciones personales y ambiciones políticas de algunos particulares; pues, además de las razones que exponen en las quejas anteriores, anualmente sufren y pagan demasiado caro, la avaricia de los rematadores de los derechos agrícolas y mobiliario, quienes a nombre del Estado cometen mayores o iguales atentados que los expuestos". Fiscal de la Provincia, 8 de octubre de 1878.71
\end{abstract}

-0o0o0-

\title{
Fuentes primarias
}

Argentina, Archivo Histórico de Jujuy, Cajas Documentos, correspondencia e informes de gobierno, 1850 a 1870 .

Argentina, Archivo Histórico de la Legislatura de Jujuy, Libros de Actas de Sesiones y Cajas Documentos, 1851- 1872.

Argentina, Archivo de Tribunales de la Provincia de Jujuy, Expedientes Judiciales.

\section{Fuentes secundarias}

REGISTRO OFICIAL, Compilación de Leyes y decretos de la Provincia de Jujuy, desde el año 1835 hasta el de 1884, Tomo 1, Jujuy, Publicación Oficial, 1885 .

REGISTRO OFICIAL, Compilación de Leyes y decretos de la Provincia de Jujuy, desde el año 1835 hasta el de 1884, Tomo 2, Jujuy, Publicación Oficial, 1885 .

REGISTRO OFICIAL, Compilación de Leyes y decretos de la Provincia de Jujuy, desde el año 1835 hasta el de 1884, Tomo 3, Jujuy, Publicación Oficial, 1885 .

\section{Bibliografía}

ARAMENDI, Bárbara "El distrito de la Puna y su primer subdelegado. Intendencia de Salta del Tucumán, 1784- 1795”, Fronteras de la historia,

${ }^{71}$ AHJ, Caja Documento, año 1878. 
Instituto Colombiano de Antropología e Historia, vol. 22, $\mathrm{n}^{\circ} 1,2017, \mathrm{pp}$. 12-37. Recuperado el 18 de mayo de 2018 de http://www.scielo.org.co/pdf/frh/v22n1/2027-4688-frh-22-01o0012.pdf.

BARRIERA, Darío, "Justicias, jueces y culturas jurídicas en el siglo XIX rioplatense", Nuevo Mundo Mundos Nuevos, Ecole des hautes études en sciences sociales, Francia, 2010. Recuperado el 23 de febrero de 2018 de http://journals.openedition.org/nuevomundo/59252.

BARRIERA, Darío "Justicia de proximidad, pasado y presente, entre la historia y el derecho", PolHis, año 5, n ${ }^{\circ} 10$, segundo semestre 2012, pp. 50- 57. Recuperado el 28 de mayo de 2018 de http://www.historiapolitica.com/datos/boletin/Polhis10 BARRIERA.pd f.

BECERRA, María Florencia; ESTRUCH, Dolores, "Alcaldes de mina, capitulares, cateadores y mineros. Una reflexión sobre la administración de la justicia en las causas mineras de la Puna de Jujuy (siglo XVII)”, Revista de historia del derecho, Instituto de Investigaciones de Historia del Derecho, Argentina, $n^{\circ}$ 42, julio-dic. 2011, pp. 1-21. Recuperado el 18 de mayo de 2018 de http://www.scielo.org.ar/scielo.php?script=sci arttext\&pid=S185317842011000200001.

CHOQUE CANQUI, Roberto, "La servidumbre andina en Bolivia”, Rossana BARRAGÁN y Seemin QAYUM (dir.), El siglo XIX: Bolivia y América Latina, Lima, IFEA, 1997, pp. 437-447.

FALCON, Romana, El Jefe Político. Un dominio negociado en el mundo rural del Estado de México, 1856- 1911, México, El Colegio de México, 2015.

FANDOS, Cecilia, “La campaña de Jujuy entre la Guerra del Paraguay y el levantamiento de Varela. Principales manifestaciones socioeconómicas en la Quebrada de Humahuaca y Puna”, II Reunión Tendencias y Debates en Historia Económica Argentina: Coyunturas de crisis económica desde la perspectiva regional-provincial en la Argentina de los siglos XIX a XXI, San Salvador de Jujuy, 19 y 20 de octubre 2017.

FRADKIN, Raúl, "La experiencia de la Justicia: Estado, propietarios y arrendatarios en la campaña bonaerense (1800-1830)", Raúl FRADKIN (comp.), 'La ley es la tela de araña'. Ley justicia y sociedad rural en Buenos Aires, 1780-1830, Buenos Aires, Prometeo, 2009, pp. 83-120.

GALANTE, Mirian, "La historiografía reciente de la justicia en México, siglo XIX: perspectivas, temas y aportes”, Revista Complutense de Historia de América, Universidad Complutense de Madrid, vol. 37, 2011, pp. 93- 115.

GIL MONTERO, Raquel, "Población, medio ambiente y economía en la Puna de Jujuy, Argentina, Siglo xix", Revista de Demografía Histórica, Asociación de Demografía Histórica, España, vol. XXII, nº 1, 2004, pp. 185-208.

GROSSI, Paolo, “Absolutismo jurídico y derecho privado en el siglo XIX", Derecho \& Sociedad, Facultad de Derecho de la PUCP, n 11, 1996, pp. 
94-99. Recuperado el 2 de febrero de 2018 de http://revistas.pucp.edu.pe/index.php/derechoysociedad/issue/view/121 5 .

IRUROZQUI, Marta, "Presentación: Otra vuelta de tuercas. Justicia y violencia política en Iberoamérica, siglo XIX”, Revista de Indias, Consejo Superior de Investigaciones Científicas, vol. LXXVI, ${ }^{\circ}$ 266, 2016, pp. 3-16.

MADRAZO, Guillermo, Hacienda y encomienda en los Andes. La Puna de Jujuy bajo el marquesado de Tojo, siglos XVII-XIX, Buenos Aires, Fondo Editorial, 1982.

PAZ, Gustavo, "Gran propiedad y grandes propietarios en Jujuy a mediados del siglo XIX”, Cuadernos, FHyCS-UNJu, nº 21, 2003, pp. 11-22.

PAZ, Gustavo, "Resistencia y rebelión campesina en la Puna de Jujuy, 18501875", Boletín del Instituto de Historia Argentina y Americana "Dr. Emilio Ravignani”, Tercera serie, ${ }^{\circ}$ 4, $2^{\circ}$ semestre 1991, pp. 63-89.

QUIJADA, Mónica “La caja de Pandora. El sujeto político indígena en la construcción del orden liberal”, Historia Contemporánea, $\mathrm{n}^{\circ} 33,2006$, pp. 605-637.

SICA, Gabriela y ULLOA, Mónica, "Jujuy en la colonia. De la fundación de la Ciudad a la crisis del Orden colonial”, Ana TERUEL y Marcelo LAGOS (dir.), Jujuy en la Historia. De la colonia al siglo XX, Jujuy, EDIUNJu, 2010, pp. 43-84.

TÍO VALLEJO, Gabriela, "Los historiadores 'hacen justicia': un atajo hacia la sociedad y el poder en la campaña rioplatense en la primera mitad del siglo XIX", Revista de historia del derecho, Instituto de Investigaciones de Historia del Derecho, $\mathrm{n}^{\mathrm{o}}$ 41, enero-junio 2011, pp. 199-212. Recuperado el 24 de febrero de 2018, de http://www.scielo.org.ar/scielo.php?script=sci_arttext\&pid=S1853$17842011000100006 \& \operatorname{lng}=\mathrm{es} \& \ln \mathrm{ln}=\mathrm{es}$. 